\title{
Identification of quantitative trait loci for
} mineral elements in grains and grass powder of barley

\author{
Y.W. Zeng ${ }^{1 *}$, J. Du ${ }^{1 *}$, X.M. Yang ${ }^{1 *}$, X.Y. Pu ${ }^{1}$, L.X. Wang ${ }^{2}$, J.Z. Yang ${ }^{1}$, \\ L.J. Du ${ }^{2}$, T. Yang ${ }^{1}$, S.M. Yang ${ }^{1}$ and Z.H. Sun ${ }^{1,3}$ \\ ${ }^{1}$ Biotechnology and Genetic Resources Institute, \\ Yunnan Academy of Agricultural Sciences, Kunming, Yunnan Province, China \\ ${ }^{2}$ Institute of Quality Standards and Testing Technology, \\ Yunnan Academy of Agricultural Sciences, Yunnan Province, China \\ ${ }^{3}$ Science and Technology Department, Southwest Forestry University, \\ Yunnan Province, China \\ *These authors contributed equally to this study. \\ Corresponding author: Y.W. Zeng \\ E-mail: zengyw1967@126.com
}

Genet. Mol. Res. 15 (4): gmr15049103

Received August 29, 2016

Accepted October 18, 2016

Published December 2, 2016

DOI http://dx.doi.org/10.4238/gmr15049103

Copyright (C) 2016 The Authors. This is an open-access article distributed under the terms of the Creative Commons Attribution ShareAlike (CC BY-SA) 4.0 License.

ABSTRACT. Mineral elements in barley (Hordeum vulgare) play
an important physiological role in global human health. In this study,
quantitative trait loci (QTLs) for concentration of nine mineral elements
in barley grain and grass powder were detected in a population of 193
recombinant inbred lines of the barley cross Ziguangmangluoerling
x Schooner and the parents. We observed large genetic variation
contributing to element concentrations in both grains and grass powder.
The mean $\mathrm{K}$, Ca, and Fe concentrations in grass powder were 6.67 ,
12.00, and 4.58 times that of regenerating barley grains. In grains, 17 
QTLs that accounted for 6.36-64.08\% of the phenotypic variation in $\mathrm{Zn}, \mathrm{Mg}, \mathrm{Ca}, \mathrm{K}, \mathrm{Na}, \mathrm{Mn}, \mathrm{Fe}$, and $\mathrm{P}$ concentrations were identified. In grass powder, seven QTLs were identified; these accounted for 6.03$21.86 \%$ of the variation in $\mathrm{Ca}, \mathrm{Zn}, \mathrm{Mg}, \mathrm{K}, \mathrm{Fe}$, and $\mathrm{Cu}$ concentrations. These QTLs affecting elements in grain and grass powder are so far unreported in barley. To our knowledge, QTLs with pleiotropic effects for three elements were also identified for the first time in barley. The qK1/qMg1/qCal region between markers Bmag0211 and GBMS0014 on chromosome $1 \mathrm{H}$ was shown to have large additive effects for $\mathrm{Mg}$, $\mathrm{Ca}$, and $\mathrm{K}$ concentrations in grains. These additive effects indicated that the high element ( $\mathrm{Mg}, \mathrm{Ca}, \mathrm{Zn}, \mathrm{Mn}$, and $\mathrm{K}$ ) alleles were contributed by Ziguangmangluoerling. These results will further our understanding of the genetic basis of mineral elements and help us develop markers linked with mineral elements for marker-assisted selection breeding in barley.

Key words: Quantitative trait locus; Mineral element; Grain; Grass powder; Recombinant inbred lines; Barley

\section{INTRODUCTION}

Mineral elements found in crop grain play an important role in human health (Huang et al., 2015; Kashian and Fathivand, 2015). The WHO recommends consuming $<2.00 \mathrm{~g} \mathrm{Na}$ and more than $3.51 \mathrm{~g} \mathrm{~K}$ per person per day (Drewnowski et al., 2015a). Deficiencies of Ca, Fe, and $\mathrm{Zn}$ in the diet are a key problem of global health (Myers et al., 2014; Drewnowski et al., 2015b). Trace elements, such as $\mathrm{Fe}, \mathrm{Zn}, \mathrm{Cu}$, and $\mathrm{Mn}$, are essential for maintaining health, immunity, growth, production, and reproduction of animals (Santos et al., 2015). Eight single nucleotide polymorphism loci have been shown to be significantly associated with concentrations of $\mathrm{Ca}$, $\mathrm{Cu}, \mathrm{K}, \mathrm{Na}$, and $\mathrm{Zn}$ in brown rice (Huang et al., 2016). The barley (Hordeum vulgare) genome encodes a subset of 10 metallothioneins (MTs) that is specifically involved in $\mathrm{Cu}$ detoxification (Schiller et al., 2014). Zn starvation was found to lead to up-regulation of MT1a, whereas $\mathrm{Cu}$ starvation up-regulated MT2a, which has two Cu-responsive elements in the promoter (Schiller et al., 2014). A major reason for the outbreak of many chronic human diseases has been suggested to be the transition of the staple food from ancient brown rice and barley to modern polished rice and wheat fine flour, resulting in loss of intake of mineral elements (Zeng et al., 2013).

Barley grass powder and grains are very important for human health, especially their contents of bioactive compounds, including the polyphenols, beta-glucan, superoxide dismutase, lutonarin, and saponarin. However, mineral elements also possess multiple health benefits. Fe-S clusters are very important for origin of life especially acetyl-CoA, DNA, and RNA world (Fuss et al., 2015). Low Ca absorption is associated with osteoporosis and fracture (Chang et al., 2015). $\mathrm{Mg}$ intake around $400 \mathrm{mg} /$ day is associated with a lower incidence of colorectal cancer in postmenopausal women (Gorczyca et al., 2015). Lower Na and higher K intake as well as antiobesity were associated with lower the risk of hypertension (Chen et al., 2015). Barley grass powder of young green barley leaves possesses properties that help blood flow, digestion, and general detoxification (Lahouar et al., 2015). The grass powder also has antioxidant and anti-inflammatory activity, and prevention of chronic diseases may be related to the bioactive compounds superoxide dismutase, lutonarin, and saponarin (Lahouar et al., 2015).

Genetics and Molecular Research 15 (4): gmr15049103 
The order of element concentrations $(\mathrm{mg} / \mathrm{kg})$ in barley grains is $\mathrm{K}(4900)>\mathrm{P}(4125)$ $>\mathrm{Mg}(1425)>\mathrm{Ca}(625)>\mathrm{Fe}(50.1)>\mathrm{Zn}(26.8)>\mathrm{Mn}$ (15.9) $>\mathrm{Cu}$ (4.94) (Hejcman et al., 2013). In grass powder, it is $\mathrm{K}(49,753)>\mathrm{Ca}(8688)>\mathrm{Mg}(5847)>\mathrm{Fe}(29.2)>\mathrm{Se}(26.4)>$ $\mathrm{Zn} \mathrm{(20.5)}>\mathrm{Cu}$ (7.2) $>\mathrm{Mn}$ (5.2) (Hui and Tian, 2010). Breeding barley cultivars with high concentrations of $\mathrm{K}, \mathrm{Ca}, \mathrm{Fe}$, and $\mathrm{Zn}$ is an effective and economic means of solving element deficiencies and, thus, potentially mitigate some global health problems.

Quantitative trait loci (QTL) analysis has proven useful for identifying and localizing favorable alleles in barley. Alleles have been identified for grain water uptake (Cu et al., 2016), spring drought (Fiust et al., 2015), malt extract (Wang et al., 2015a), limit dextrinase (Wang et al., 2015b), semi-dwarf genes (Li et al., 2015a), and dwarfing gene btwdl (Ren et al., 2014). The concentrations of mineral elements in barley are genetically complex traits, and there is large genotypic variation in the primary barley gene pool. The genetics of mineral elements in barley appear to be quantitatively inherited. However, QTL analysis information of element concentrations in grass powder and barley grains is unreported so far. In this study, QTLs and concentrations of nine mineral elements in grass powder and regenerating barley grains were determined, using ICP-AES analysis. This may not only provide a better understanding of the genetic mechanisms governing mineral element concentration in grains and grass powder, but could also benefit genetic improvement of $\mathrm{Fe}, \mathrm{Zn}$, and $\mathrm{Ca}$ contents in barley functional foods by pyramiding favorable QTLs.

\section{MATERIAL AND METHODS}

\section{Plant materials}

A barley RIL population consisting of $193 \mathrm{~F}_{8}$-derived lines was developed from a cross between two two-rowed barley varieties, Ziguangmangluoerling and Schooner. The two parents differ significantly in element concentration in both grains and grass powder. Ziguangmangluoerling is a two-rowed, hull-less barley landrace with high concentrations of $\mathrm{P}, \mathrm{Zn}, \mathrm{Mn}, \mathrm{Mg}, \mathrm{Ca}$, and $\mathrm{Cu}$, and low $\mathrm{Fe}, \mathrm{Na}$, and $\mathrm{K}$ in the grains. The grass powder of this variety has high concentrations of $\mathrm{Fe}, \mathrm{Cu}$, and $\mathrm{K}$, and low concentrations of $\mathrm{P}, \mathrm{Zn}, \mathrm{Mn}, \mathrm{Mg}$, $\mathrm{Ca}$, and $\mathrm{Na}$. Schooner is a two-rowed, hulled malting barley cultivar with high concentrations of $\mathrm{Fe}, \mathrm{Na}$, and $\mathrm{K}$, and low concentrations of $\mathrm{P}, \mathrm{S}, \mathrm{Zn}, \mathrm{Mn}, \mathrm{Mg}, \mathrm{Ca}$, and $\mathrm{Cu}$ in the grains. In contrast, the grass powder contains high concentrations of $\mathrm{P}, \mathrm{Zn}, \mathrm{Mn}, \mathrm{Mg}, \mathrm{Ca}$, and $\mathrm{Na}$, and low concentrations of $\mathrm{Fe}, \mathrm{Cu}$, and $\mathrm{K}$.

\section{Determination of mineral element concentrations}

ICP-AES determination and analysis conditions were carried out as previously described (Zeng et al., 2009, 2010). The 193 barley RILs and their parents (Schooner and Ziguangmangluoerling) were planted in Yanhe town (1638 m above sea level) of Yuxi prefecture in Yunnan Province, China in the fall of 2012-2013. The phenotypic value of each line in a test environment was taken as the average of two replicates. Barley grass was cut and dried in the elongation stage, the character of regeneration barley all developed normally in the field with watering and fertilizing except those that had a plant height $<15 \mathrm{~cm}$. From each of the 193 RILs and their parents, $10 \mathrm{~g}$ grains and $10 \mathrm{~g}$ grass powder were ground into powder, followed by dry storing at $4^{\circ} \mathrm{C}$. Samples were digested using a wet method and any

Genetics and Molecular Research 15 (4): gmr15049103 
residues were dissolved using hydrochloric acid to convert elements into the inorganic ion state as follows: Subsequently, $0.5 \mathrm{~g}$ each sample was added to $5 \mathrm{~mL}$ nitric acid and $1 \mathrm{~mL}$ chloric acid, heated until the solution was clear, and steamed to nearly dry on an electric hot plate. To dissolve the residue, $5 \mathrm{~mL}$ hydrochloric acid (1:1) was added, followed by transfer to a $50 \mathrm{~mL}$ volumetric flask. This was repeated three times per sample while processing a blank sample at the same time. Analyses were then performed by plasma emission spectrometer. This method proved to be simple, rapid, highly sensitive, and accurate, and can be used to assay several elements at the same time. The recovery ratio obtained by standard addition method ranged between 93.5 and $110.2 \%$, and the relative standard deviation ranged from 1.7 to $4.6 \%$. The solution was analyzed for eight elements (P, K, Ca, Mg, Fe, $\mathrm{Zn}, \mathrm{Cu}, \mathrm{Na}$, and $\mathrm{Mn}$ ) in both grains and grass powder, using ICP-AES (Zeng et al., 2010). The SPSS 16.0 software was used to perform descriptive statistics of the RIL population and to investigate the mineral element concentrations.

\section{DNA extraction, primer selection, and polymerase chain reaction (PCR)}

Total genomic DNA was extracted from fresh leaves of the $\mathrm{F}_{9}$ RIL plants using the CTAB method (Rogers and Bendich, 1988), with minor modifications. We used 604 sequence primers, to make a genetic linkage map of seven chromosomes consisting of 775 simple sequence repeat (SSR) marker loci representing six populations (Varshney et al., 2007). These SSR markers were synthetized by Beijing Dingguo Changsheng Biotechnology Co. Ltd. A $10-\mu \mathrm{L}$ reaction mixture containing $1.5 \mu \mathrm{L}$ PCR buffer $(20 \mathrm{mM}$ Tris, $\mathrm{pH} 8.0,50 \mathrm{mM} \mathrm{KCl}, 2.5$ $\mathrm{mM} \mathrm{MgCl} 2,0.1 \mathrm{mM}$ EDTA, $1 \mathrm{mM}$ DTT, and 50\% glycerol), $2 \mu \mathrm{L}$ DNA, $0.5 \mu \mathrm{L}$ forward and reverse primers, $0.4 \mu \mathrm{L}$ each dNTPs, $0.2 \mu \mathrm{L}$ Taq polymerase, and $4.9 \mu \mathrm{L} \mathrm{ddH}_{2} \mathrm{O}$. The PCR was done on a Biometra T gradient PCR machine (Goettingen, Germany) using a protocol consisting of an initial denaturation at $94^{\circ} \mathrm{C}$ for $5 \mathrm{~min}$, followed by 35 cycles of denaturation at $94^{\circ} \mathrm{C}$ for $40 \mathrm{~s}$; annealing at $55^{\circ} \mathrm{C}$ (depending on the individual SSR primer) for $40 \mathrm{~s}$; and extension at $72^{\circ} \mathrm{C}$ for $1 \mathrm{~min}$, followed by a 5 -min final extension at $72^{\circ} \mathrm{C}$. The PCR products were separated on $8 \%$ polyacrylamide gel by electrophoresis for $2 \mathrm{~h}$ at $180 \mathrm{~V}$. Bands were detected using a silver-staining method (Varshney et al., 2007).

\section{QTL analysis}

To screen polymorphism between Ziguangmangluoerling and Schooner, 604 SSR markers distributed across all seven barley chromosomes were used. A set of 180 polymorphic SSR markers were used to genotype the 193 RILs and the two parents, which were then used to identify the linkage groups. PCR products that had the same band size as Ziguangmangluoerling were denoted 0 , those that had the same band size as Schooner were denoted 2, heterozygotes were denoted 1, and all others were denoted -1 . Genetic linkage groups were identified using the QTL IciMappingV3.3 software (http://www.isbreeding.net; Meng et al., 2015). The genetic map spanned $2671 \mathrm{cM}$ providing an average density of one SSR marker per $14.84 \mathrm{cM}$ based on the Ziguangmangluoerling x Schooner RILs, which contained 180 SSR markers with an average of 26 markers per linkage group (unpublished data). The QTLs and genetic effects associated with the mineral element concentrations were identified using inclusive composite interval mapping analysis using the IciMappingV3.3 software (Wang, 2009). A threshold value of LOD $\geq 2.5$ was used to identify the presence of a putative QTL (Wang, 2009) and estimated genetic parameters. The percentage phenotypic variance (i.e., genetic contribution)

Genetics and Molecular Research 15 (4): gmr15049103 
explained by each QTL, and its additive effects were estimated. QTLs were named according to McCouch et al. (1997), but in alphabetic order for QTLs on the same chromosome.

\section{RESULTS}

\section{Variation in element concentration in the parents and RILs}

Compared with Schooner, a two-rowed and hulled malting barley cultivar, Ziguangmangluoerling is a two-rowed, hull-less barley landrace with high grain concentrations of $\mathrm{P}, \mathrm{K}, \mathrm{Mg}, \mathrm{Ca}, \mathrm{Fe}, \mathrm{Zn}, \mathrm{Mn}$, and $\mathrm{Cu}$, and low concentration of $\mathrm{Na}$; In its grass powder, the concentrations of $\mathrm{Fe}, \mathrm{Cu}$, and $\mathrm{K}$ are high, whereas $\mathrm{P}, \mathrm{Zn}, \mathrm{Mn}, \mathrm{Mg}, \mathrm{Ca}$, and $\mathrm{Na}$ are low (Table 1). The phenotypic differences in mineral element concentrations in grains and grass powder between Ziguangmangluoerling, Schooner, and the RILs are presented in Table 1.

Table 1. Genetic variation in mineral concentrations in grains and grass powderforthe 195RILs and the two parents.

\begin{tabular}{|c|c|c|c|c|c|c|c|c|c|}
\hline \multirow[t]{2}{*}{ Trait } & \multirow[t]{2}{*}{ Product } & \multicolumn{2}{|c|}{ Parent $(\mathrm{mg} / \mathrm{kg})$} & \multicolumn{6}{|c|}{ RIL population } \\
\hline & & ZGM* & $\mathrm{SCH}^{*}$ & Mean & Range & CV (\%) & Variance & Skewness & Kurtosis \\
\hline \multirow[t]{2}{*}{$\mathrm{P}$} & Barley grains & 2772.0 & 1867.00 & 2585.6 & 5601.1 & 40.4 & $108,800.0$ & 0.86 & 0.45 \\
\hline & Grass powder & 3645.0 & 3890.00 & 4187.9 & 3270.0 & 11.6 & $23,700.0$ & 0.07 & 1.43 \\
\hline \multirow[t]{2}{*}{ K } & Barley grains & 4690.0 & 3889.00 & 4801.7 & 8499.0 & 38.4 & $340,000.0$ & -0.11 & -0.35 \\
\hline & Grass powder & $32,200.0$ & $22,900.0$ & $31,828.0$ & $44,900.0$ & 28.1 & $797,8000.0$ & 0.00 & -0.65 \\
\hline \multirow[t]{2}{*}{$\mathrm{Mg}$} & Barley grains & 1364.0 & 917.2 & 1248.6 & 1797.6 & 31.5 & $15,480.0$ & -0.53 & -0.54 \\
\hline & Grass powder & 2015.0 & 3020.0 & 2470.7 & 2190.0 & 15.3 & $14,330.0$ & -0.17 & 0.19 \\
\hline \multirow[t]{2}{*}{$\mathrm{Ca}$} & Barley grains & 582.8 & 461.3 & 567.7 & 1086.6 & 41.5 & $55,474.9$ & -0.19 & -0.80 \\
\hline & Grass powder & 6250.0 & 6320.0 & 6786.5 & 7690.0 & 2.0 & $188,100.0$ & 0.47 & -0.19 \\
\hline \multirow[t]{2}{*}{$\mathrm{Na}$} & Barley grains & 157.6 & 165.9 & 189.9 & 605.8 & 55.1 & $10,936.3$ & 0.87 & 1.67 \\
\hline & Grass powder & 3040.0 & 6630.0 & 4327.6 & $14,160.0$ & 43.5 & $354,300.0$ & 1.54 & 5.86 \\
\hline \multirow[t]{2}{*}{$\mathrm{Fe}$} & Barley grains & 58.7 & 42.8 & 52.9 & 235.0 & 59.1 & 976.9 & 1.55 & 6.38 \\
\hline & Grass powder & 252.0 & 248.0 & 241.3 & 405.1 & 22.9 & 3057.2 & 0.19 & 2.62 \\
\hline \multirow[t]{2}{*}{$\mathrm{Zn}$} & Barley grains & 50.8 & 25.9 & 39.5 & 66.8 & 39.5 & 242.6 & -0.00 & -0.86 \\
\hline & Grass powder & 37.1 & 69.2 & 56.8 & 68.9 & 23.2 & 173.4 & 0.24 & 0.30 \\
\hline \multirow[t]{2}{*}{$\mathrm{Cu}$} & Barley grains & 16.1 & 11.2 & 14.1 & 67.4 & 72.9 & 106.0 & 2.35 & 7.87 \\
\hline & Grass powder & 42.7 & 11.9 & 10.5 & 14.7 & 15.0 & 2.5 & 1.62 & 8.76 \\
\hline \multirow[t]{2}{*}{$\mathrm{Mn}$} & Barley grains & 19.7 & 17.1 & 29.1 & 114.2 & 85.2 & 613.7 & 1.67 & 1.88 \\
\hline & Grass powder & 29.1 & 69.4 & 41.3 & 52.3 & 17.2 & 50.7 & 0.82 & 0.18 \\
\hline
\end{tabular}

*ZGM = Ziguangmangluoerling, $\mathrm{SCH}=$ Schooner.

The frequency distributions of macroelement concentrations $(\mathrm{P}, \mathrm{K}, \mathrm{Mg}, \mathrm{Ca}$, and $\mathrm{Na}$ ) in regenerating barley grains and grass powder for RILs derived from Ziguangmangluoerling $\mathrm{x}$ Schooner are presented in Figure 1 and Table 1. The concentrations of $\mathrm{P}$ and $\mathrm{Mg}$ in grains were both found to be highest in Ziguangmangluoerling, followed by the RILs and Schooner. However, the concentrations of $\mathrm{K}$ in grass powder was higher in Ziguangmangluoerling and RILs compared to in Schooner. The concentrations of $\mathrm{Mg}$ and $\mathrm{Na}$ in grass powder were both found to be highest in Schooner, followed by the RILs and Ziguangmangluoerling. The concentration of $\mathrm{Na}$ in grass powder was approximately twice as high in Schooner compared to that observed in Ziguangmangluoerling, whereas the RILs showed an intermediate Na concentration. The concentrations of $\mathrm{K}$ and $\mathrm{Na}$ in grains were both found to be highest in RILs, followed by the Ziguangmangluoerling and Schooner. The concentrations of $\mathrm{P}$ and $\mathrm{Ca}$ in grass powder were both found to be highest in RILs, followed by the Ziguangmangluoerling and Schooner.

Two $(\mathrm{P}, \mathrm{Mg}$, and $\mathrm{Ca}$ ) or three peak $(\mathrm{K})$ continuous distributions were observed in the RIL population for four macroelements in grains except $\mathrm{Na}$ (single peak). However, single

Genetics and Molecular Research 15 (4): gmr15049103 
peak continuous distribution were observed in four macroelements $(\mathrm{P}, \mathrm{Mg}, \mathrm{Ca}$, and $\mathrm{Na}$ ) in grass powder, except $\mathrm{K}$ (two peak), and with the exception of $\mathrm{Na}$, the average $\mathrm{P}, \mathrm{K}, \mathrm{Mg}$, and $\mathrm{Ca}$ concentrations in both grains and grass powder were close to average of Ziguangmangluoerling and Schooner, i.e., their mid-parent value (Figure 1). This indicates that all the five elements were quantitative traits controlled by multiple genes, which satisfies the demands for QTL analysis.
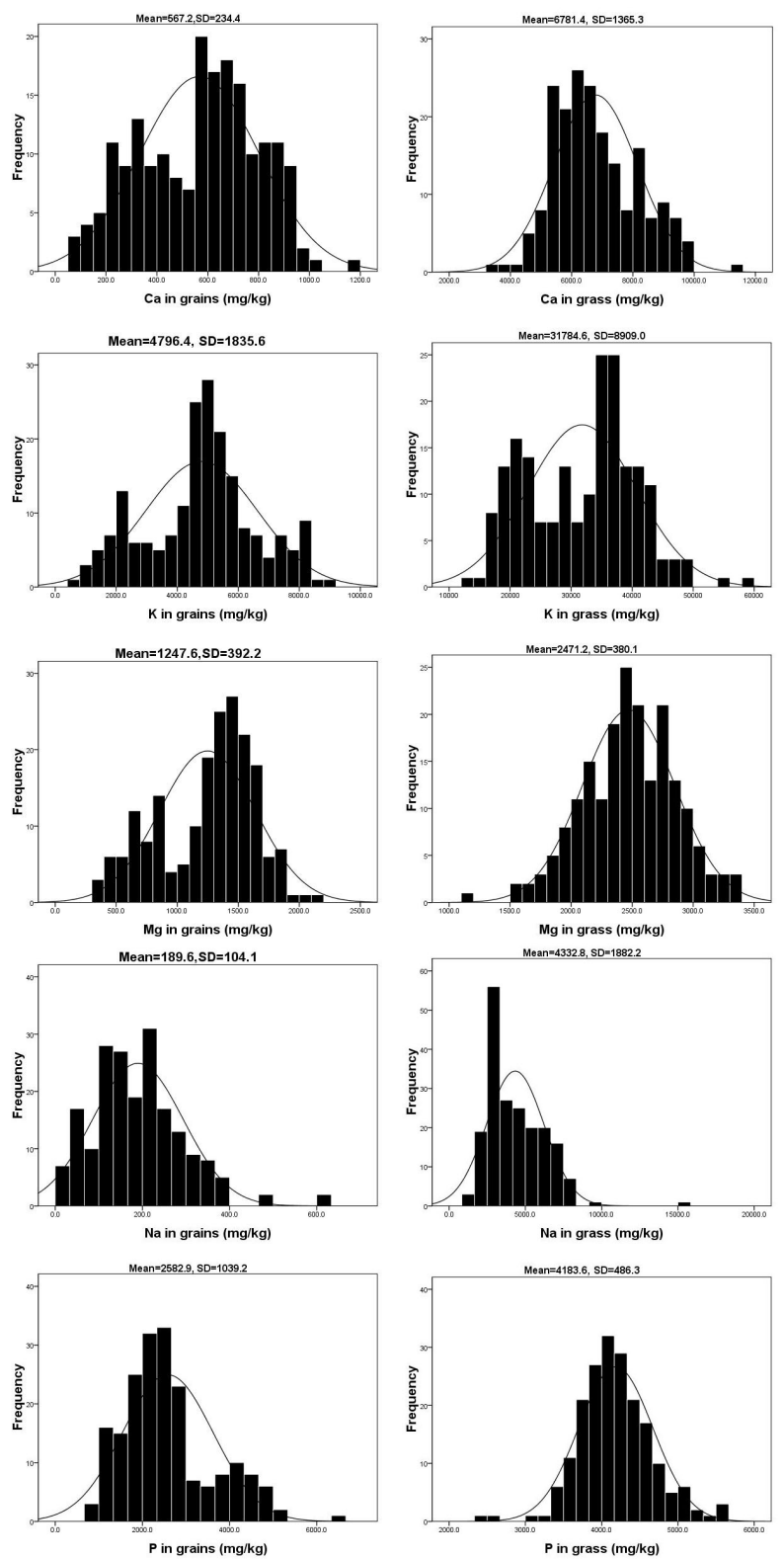

Figure 1. Frequency distributions of the concentrations of macroelements $\mathrm{P}, \mathrm{K}, \mathrm{Mg}, \mathrm{Ca}$, and $\mathrm{Na}$ in barley grains and grass powder in 193 RILs derived from Ziguangmangluoerling x Schooner. 
The frequency distributions of the microelement concentrations ( $\mathrm{Fe}, \mathrm{Zn}, \mathrm{Cu}$, and $\mathrm{Mn}$ ) in regenerating barley grains and grass powder for RILs derived from Ziguangmangluoerling $\mathrm{x}$ Schooner are presented in Figure 2 and Table 1. The concentrations of $\mathrm{Fe}, \mathrm{Zn}$ and $\mathrm{Cu}$ in grains were found to be highest in Ziguangmangluoerling, followed by the RILs and Schooner. However, the concentrations of $\mathrm{Fe}$ and $\mathrm{Cu}$ in grass powder were both found to be highest in Ziguangmangluoerling, followed by the RILs and Schooner. The concentrations of $\mathrm{Zn}$ and $\mathrm{Mn}$ in grass powder were approximately twice as high in Schooner compared to that observed in Ziguangmangluoerling, whereas the RILs showed an intermediate $\mathrm{Zn}$ and $\mathrm{Mn}$ concentration. The concentrations of $\mathrm{Mn}$ in grains were found to be highest in RILs, followed by the Ziguangmangluoerling and Schooner.

Single-peak ( $\mathrm{Fe}$ and $\mathrm{Cu}$ ) or two-peak ( $\mathrm{Zn}$ and $\mathrm{Mn}$ ) continuous distributions in grains and single-peak ( $\mathrm{Fe}, \mathrm{Zn}, \mathrm{Cu}$ and $\mathrm{Mn}$ ) continuous distributions in grass powder were observed in the RIL population for all four microelements (Figure 2). The average concentrations of Fe, $\mathrm{Zn}$, and $\mathrm{Cu}$ in the grains and the average concentrations of $\mathrm{Fe}, \mathrm{Zn}$, and $\mathrm{Mn}$ in grass powder were close to their respective mid-parent values (Figure 2), indicating that these three elements were quantitative traits controlled by multiple genes and, thus, satisfied the demands for QTL analysis.
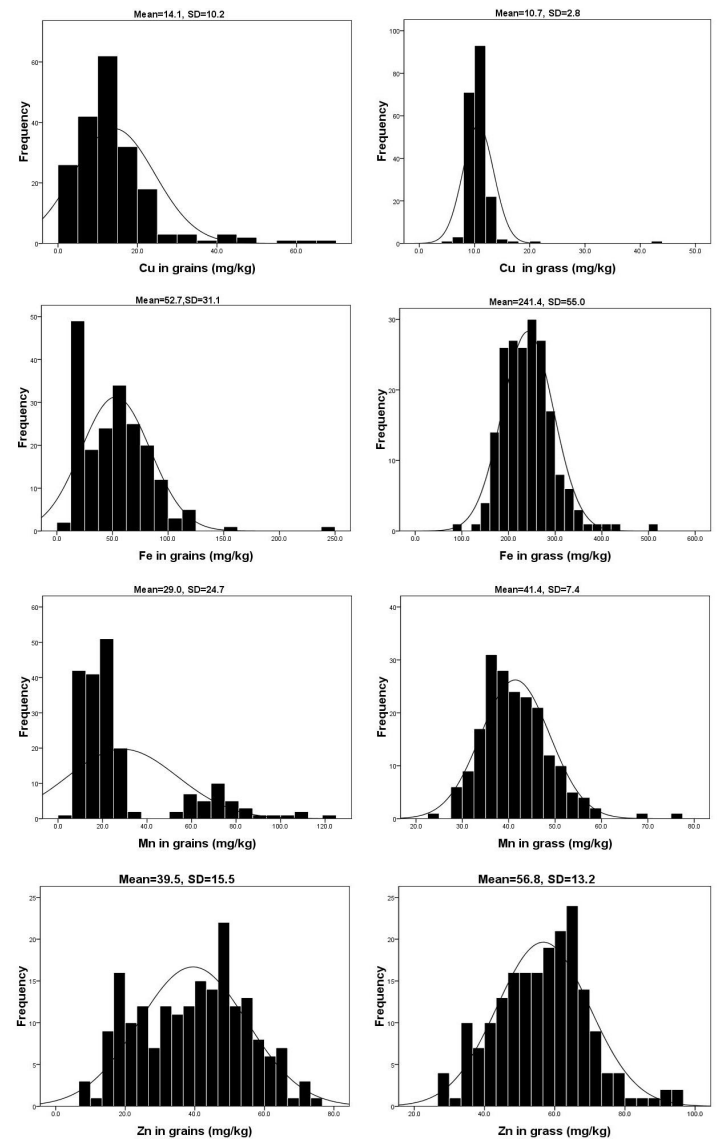

Figure 2. Frequency distributions of concentrations of microelements $\mathrm{Fe}, \mathrm{Zn}, \mathrm{Cu}$, and $\mathrm{Mg}$ in barley grains and grass powder in 193 RILs derived from Ziguangmangluoerling x Schooner. 


\section{Detection of QTL for element concentrations in regenerating barley grains}

We identified 17 QTLs for eight element concentrations (P, K, Mg, Ca, Na, Fe, Zn, and $\mathrm{Mn}$ ) in regenerating barley grains were unreported so far. The average phenotypic variances explained (PVE) by these 17 QTLs ranged from 6.36 to $64.08 \%$, as identified in the RIL population (Table 2). Specifically, the first co-localizations of QTLs for $q K 1 / q M g 1 / q C a 1$ region for Bmag0211-Gbms0014 were identified on chromosome 1H; the average PVE of $q K 1, q M g 1$, and $q \mathrm{Cal}$ were from 34.28 to $62.51 \%$, indicating that they were major QTLs for macroelements (K, Ca, and $\mathrm{Mg}$ ) with a potential health effect. QTLs $q \mathrm{Cal}, q \mathrm{Ca}$, and $q \mathrm{Ca} 7$ for $\mathrm{Ca}$ were identified on chromosomes $1 \mathrm{H}, 6 \mathrm{H}$, and $7 \mathrm{H}$ in RILs with favorable alleles, all from the parent Ziguangmangluoerling, which was shown to have the largest effects for Ca concentrations in grains. The average PVE of $q \mathrm{Ca} 1, q \mathrm{Ca} 6$, and $q \mathrm{Ca} 7$ were from 62.51 to $62.34 \%$, indicating that they were major QTLs for Ca concentrations in grains. In addition, QTLs $q M g 7-1$ and $q Z n 7-2$ for $\mathrm{Mg}$ and $\mathrm{Zn}$ concentrations, respectively, were identified on chromosome $7 \mathrm{H}$ in the RILs with favorable alleles all from the parent Ziguangmangluoerling. The average PVE of $q M g 7-1$ and $q Z n 7-2$ were 49.41 and $44.21 \%$, respectively, indicating that they were major QTLs for Mg and Zn concentrations in grains. QTL $q N a 4$ for Na concentration was identified on chromosome $4 \mathrm{H}$ in RILs with favorable alleles from the parent Schooner. The average PVE of $q N a 4$ was $12.31 \%$, indicating that it was major QTL for Na concentrations in grains.

Table 2. QTLs for element concentration in barley grains identified in a population of 195 RILs.

\begin{tabular}{|c|c|c|c|c|c|c|c|}
\hline Trait & QTL & Chr. $^{\text {a }}$ & Marker interval & Interval $(\mathrm{cM})$ & $\mathrm{LOD}^{\mathrm{b}}$ & $\mathrm{PVE}^{\mathrm{c}}(\%)$ & Additive effect \\
\hline $\mathrm{P}$ & $q P 7$ & $7 \mathrm{H}$ & Bmag0914-Gbm1464 & 10.46 & 2.75 & 6.36 & -265.93 \\
\hline \multirow[t]{2}{*}{$\mathrm{K}$} & $q K 1$ & $1 \mathrm{H}$ & Bmag0211-Gbms0014 & 60.73 & 3.84 & 34.28 & 1090.82 \\
\hline & $q K 7$ & $7 \mathrm{H}$ & Hvcabg-Ebmac713 & 60.74 & 3.02 & 6.42 & -481.71 \\
\hline \multirow[t]{3}{*}{$\mathrm{Mg}$} & $q M g 1$ & $1 \mathrm{H}$ & Bmag0211-Gbms0014 & 60.73 & 4.04 & 55.37 & 302.57 \\
\hline & $q M g 7-1$ & $7 \mathrm{H}$ & Bmac0156-Bmag0007 & 71.62 & 2.74 & 49.41 & 277.61 \\
\hline & $q M g 7-2$ & $7 \mathrm{H}$ & Bmac0273-Ebmac0764 & 26.45 & 2.90 & 7.07 & 106.56 \\
\hline \multirow[t]{3}{*}{$\mathrm{Ca}$} & $q C a 1$ & $1 \mathrm{H}$ & Bmag0211-Gbms0014 & 60.73 & 4.34 & 62.51 & 189.89 \\
\hline & $q \mathrm{Ca}$ & $6 \mathrm{H}$ & Bmag0174-Gbm1270 & 91.33 & 4.60 & 64.08 & -191.23 \\
\hline & $q \mathrm{Ca} 7$ & $7 \mathrm{H}$ & Bmac0156-Bmag0007 & 71.62 & 5.30 & 62.34 & 186.78 \\
\hline \multirow[t]{2}{*}{$\mathrm{Na}$} & $q N a 4$ & $4 \mathrm{H}$ & Bmag0808-Bmag0740 & 16.19 & 4.53 & 12.31 & 36.66 \\
\hline & $q \mathrm{Na} 7$ & $7 \mathrm{H}$ & Bmag0507-Bmag0321 & 3.32 & 3.35 & 7.58 & 29.70 \\
\hline $\mathrm{Fe}$ & $q \mathrm{Fe} 2$ & $2 \mathrm{H}$ & Bmag0571-Bmag0378 & 41.29 & 3.34 & 7.88 & -9.43 \\
\hline \multirow[t]{3}{*}{$\mathrm{Zn}$} & $q Z n 4$ & $4 \mathrm{H}$ & Hvbammgb84-Bmag0808 & 17.72 & 3.43 & 7.37 & 4.22 \\
\hline & $q Z n 7-1$ & $7 \mathrm{H}$ & Bmag0385-Ebmac755 & 30.50 & 4.05 & 8.66 & -5.23 \\
\hline & $q Z n 7-2$ & $7 \mathrm{H}$ & Bmac0156-Bmag0007 & 71.62 & 3.02 & 44.21 & 10.33 \\
\hline \multirow[t]{2}{*}{$\mathrm{Mn}$} & $q M n 7-1$ & $7 \mathrm{H}$ & Bmag0914-Gbm1464 & 10.46 & 4.47 & 9.63 & -7.77 \\
\hline & $q M n 7-2$ & $7 \mathrm{H}$ & Bmac0162-Gbm1303 & 17.73 & 4.18 & 9.30 & 7.67 \\
\hline
\end{tabular}

${ }^{\mathrm{a}}$ Chromosome, ${ }^{\mathrm{b}}$ Genome-wide log of odd (LOD) threshold of 2.5 was determined by a 1000 -permutation test at $\mathrm{P}$

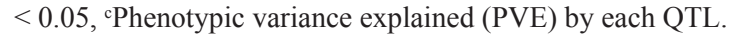

\section{Detection of QTLs for element concentrations in barley grass powder}

Seven QTLs for six element concentrations $(\mathrm{K}, \mathrm{Mg}, \mathrm{Ca}, \mathrm{Fe}, \mathrm{Zn}$, and $\mathrm{Cu})$ in barley grass powder were unreported so far. The average PVE of these seven QTLs ranged from 6.03 to $21.86 \%$ (Table 3). Specifically, QTL $q C a 3$ for Ca and QTL $q K 5$ for K concentration were identified on chromosomes $3 \mathrm{H}$ and $5 \mathrm{H}$ in RILs with favorable Ca alleles from Schooner but $\mathrm{K}$ alleles from Ziguangmangluoerling. The average PVE of $q \mathrm{Ca} 3$ and $q K 5$ were 21.85 and $16.45 \%$, respectively, indicating that they were major QTLs for $\mathrm{Ca}$ and $\mathrm{K}$ concentrations in grass powder.

Genetics and Molecular Research 15 (4): gmr15049103 
Table 3. QTLs for element concentration in barley grass powder identified in the RIL population.

\begin{tabular}{l|l|l|l|c|c|c|c}
\hline Trait & QTL & Chr. & Marker interval & Interval (cM) & LOD & PVE (\%) & Additive effect \\
\hline $\mathrm{K}$ & $q K 5$ & $5 \mathrm{H}$ & Gbms0032-Gbm5008 & 31.38 & 3.42 & 16.45 & 0.38 \\
\hline $\mathrm{Mg}$ & $q M g 7$ & $7 \mathrm{H}$ & Hvwaxy4-Gbm1326 & 11.27 & 3.02 & 8.79 & 0.01 \\
\hline $\mathrm{Ca}$ & $q C a 2$ & $2 \mathrm{H}$ & Bmag0378-Gbm1119 & 13.39 & 3.35 & 6.03 & 0.03 \\
\hline & $q \mathrm{Ca} 3$ & $3 \mathrm{H}$ & Hvltppb-Gbm1159 & 5.81 & 10.76 & 21.85 & -0.06 \\
\hline $\mathrm{Fe}$ & $q F e 3$ & $3 \mathrm{H}$ & Gbm1159-Bmag0138 & 55.45 & 3.03 & 7.33 & -15.05 \\
\hline $\mathrm{Zn}$ & $q Z n 6$ & $6 \mathrm{H}$ & Gbm1270-Ebmac0806 & 6.81 & 4.35 & 9.93 & -4.61 \\
\hline $\mathrm{Cu}$ & $q C u 2$ & $2 \mathrm{H}$ & Bmag0125-Gbm1309 & 36.40 & 4.07 & 10.69 & 0.52 \\
\hline
\end{tabular}

\section{DISCUSSION}

\section{Element concentration variation in regenerating barley grains and grass powder}

There is very large genetic variation contributing to element concentration in regenerating barley grains and grass powder (Table 1). The element concentrations of regenerating barley grains in the 193 RILs and their parents were in turn $\mathrm{K}>\mathrm{P}>\mathrm{Mg}>\mathrm{Ca}>$ $\mathrm{Na}>\mathrm{Fe}>\mathrm{Zn}>\mathrm{Mn}>\mathrm{Cu}$, whereas in grass powder they are $\mathrm{K}>\mathrm{Ca}>\mathrm{Na}>\mathrm{P}>\mathrm{Mg}>\mathrm{Fe}>$ $\mathrm{Zn}>\mathrm{Mn}>\mathrm{Cu}$. The average $\mathrm{K}, \mathrm{Ca}$, and $\mathrm{Fe}$ concentrations in grass powder were 6.67, 12.00, and 4.58 times that found in regenerating barley grains. The average concentrations for nine elements in grains were similar to those previously reported (Newman and Newman, 2008). $\mathrm{P}, \mathrm{K}, \mathrm{Mn}$, and $\mathrm{Cu}$ in grass powder were also similar to those reported previously (Yang et al., 2016). However, the $\mathrm{Na}, \mathrm{Ca}, \mathrm{Mg}, \mathrm{Fe}$, and $\mathrm{Zn}$ concentrations in barley grass powder for the 193 RILs and their parents were higher than those reported by Yang et al. (2016). The grain $\mathrm{Fe}$ and $\mathrm{Zn}$ concentrations of $92 \mathrm{H}$. spontaneum genotypes were found to average 743 and $1739 \mathrm{mg} / \mathrm{kg}$, respectively, whereas $140 \pm 5.1 \mathrm{mg} / \mathrm{kg}$ was found in Yunpi 6 (the highest cultivar of grain Fe concentration) and $98.7 \pm 5.1 \mathrm{mg} / \mathrm{kg}$ was found in Supi 4 (the highest cultivar of grain $\mathrm{Zn}$ concentration), respectively (Yan et al., 2012). Previously, the mineral elements contents $(\mathrm{mg} / \mathrm{kg})$ of barley grass have been shown to be $\mathrm{K}(27,000)>\mathrm{Na}(13,000)$ $>\mathrm{Ca}(4740)>\mathrm{Mg}(4110)>\mathrm{P}(2350)>\mathrm{Fe}(820)>\mathrm{Mn}(42.0)>\mathrm{Zn}(13.0)>\mathrm{Cu}$ (12.0) (Lin, 2005). The mean concentrations $(\mathrm{mg} / \mathrm{kg})$ of eight elements in 628 brown rice landraces were found to be $\mathrm{P}(3480)>\mathrm{K}(2540)>\mathrm{Mg}(1480)>\mathrm{Ca}(157)>\mathrm{Zn}(32.8)>\mathrm{Fe}(32.0)>\mathrm{Cu}$ (13.6) > Mn (13.2) (Zeng et al., 2010). The K, Ca, and Fe concentrations in grass powder were found to be $10.63,30.19$, and 25.63 times that of brown rice. An increased intake of $\mathrm{K}$ might be beneficial for hypertension control in humans populations (Noh et al., 2015). Dietary $\mathrm{Ca} / \mathrm{P}$ ratio is one of the indicators that can predict bone health (Arai and Sakuma, 2015). An increased $\mathrm{Ca}$ intake is associated with reduced blood pressure, reduced rate of bone loss, and a moderate risk reduction of fracture (Shiraki, 2015). Fe and n-3 long-chain polyunsaturated fatty acid have been associated with cognition, especially in children with good reading comprehension (Sørensen et al., 2015). Total Fe bioavailability in the US diet is $15.1-15.5 \%$ (Armah et al., 2015). Healthy dietary of the most major for modern humans will be the polished rice or wheat flour add grass powder (Zeng et al., 2016b).

Genetic approaches are currently being applied in barley, aiming to biofortify functional foods with essential mineral elements that are commonly lacking in human diets such as Fe, Zn, and $\mathrm{Ca}$. However, current efforts to develop barley cultivars with high mineral content associated with good agronomic performance are still very restricted. Therefore, barley grass powder could be an important functional food to solve the global mineral malnutrition problem.

Genetics and Molecular Research 15 (4): gmr15049103 


\section{QTL detection and pleiotropy for eight element concentrations in regenerating barley grains}

We identified 17 QTLs for eight element concentrations (P, K, Mg, Ca, Na, Fe, Zn, and $\mathrm{Mn}$ ) in barley grains that were unreported so far. These explained from 6.36 to $64.08 \%$ of the phenotypic variance in the RIL population in this study (Table 2). Eight major QTLs were identified on chromosomes $1 \mathrm{H}, 6 \mathrm{H}$, and $7 \mathrm{H}$ in the RILs, and explained from 12.31 to $64.08 \%$ of the phenotypic variance. These QTLs were shown to have the largest effects for four element concentrations in grains, i.e., QTLs $q K 1, q Z n 7-2, q M g 7-1, q M g 1, q C a 1, q C a 6$, and $q \mathrm{Ca} 7$ explained 34.28-64.08\% of the total phenotypic variation in four element concentrations and the favorable alleles at these loci were contributed by Ziguangmangluoerling $(\mathrm{Mg}, \mathrm{Ca}$, and $\mathrm{Zn}$ ) and Schooner (K). A comparison of the QTLs identified in this study with previously reported concentrations of these four elements in crop grains revealed that same four elements were shown to have large effects. For instance, QTLs $q K 8-1, q K 9-1, q M g 5-1, q C a 1-1$, and $q Z n 8-1$ explained 14-19\% of the total phenotypic variation in four element concentrations and the favorable alleles at these loci were contributed by wild rice (Oryza rufipogon) (GarciaOliveira et al., 2009). The $q K 6.1 / q C a 6 / q Z n 6 / q M n 6 / q C u 6$ region for major QTLs was a 29.9$\mathrm{kb}$ region flanked by RM19410 and Si2944, with the enhancing alleles derived from Milyang 46 (Yu et al., 2015). In maize, the NRAMP genes are likely responsible for the observed natural variation in maize grain $\mathrm{Zn}$ and Fe concentrations (Jin et al., 2015).

The associated QTLs for $q K 1 / q M g 1 / q C a 1$ region for Bmag0211-GBMS0014 were identified for the first time on chromosome $1 \mathrm{H}$ in barley. The average PVE of $q K 1, q M g 1$, and $q \mathrm{Cal}$ were $34.28,55.37$, and $62.51 \%$, respectively. This indicates that they were major QTLs for macroelements $\mathrm{K}, \mathrm{Ca}$, and $\mathrm{Mg}$ with potential health effects. It is noteworthy that the QTL in the Bmag0211-GBMS0014 region on chromosome $1 \mathrm{H}$ that affected the $\mathrm{K}, \mathrm{Mg}$, and Ca concentrations in the RIL population was an important QTL with a large additive effect and genetic background independence. This finding merits confirmation in other populations and fine-mapping for map-based cloning. The additive effects indicated that the alleles for higher element concentrations were contributed by Ziguangmangluoerling, and that these may be the most important components for enhancing element concentrations through methods of genealogical improvement. Significant additive genetic effects as well as parental mean effects have previously been detected for P, K, Ca, and Na (Fernandes Santos and Boiteux, 2015). Co-localization of QTLs for element concentration has previously been found in various species, such as rice (Yu et al., 2015) and in maize grain (Simić et al., 2012). Co-localization of QTLs for the $q P 3 / q M g 3 / q Z n 3$ region was shown to have the largest effects for $\mathrm{P}, \mathrm{Mg}$, and $\mathrm{Zn}$ contents, whereas the $q K 6.1 / q \mathrm{Ca} 6 / q \mathrm{Zn} 6 / q M n 6 / q C u 6$ region was found to be responsible for five of seven mineral elements in milled rice in RIL populations (Yu et al., 2015). Three QTLs for $\mathrm{Fe} / \mathrm{P}, \mathrm{Zn} / \mathrm{P}$, and $\mathrm{Mg} / \mathrm{P}$ were co-localized on chromosome 3 in maize, coinciding with the SSR marker bnlg1456 (Simić et al., 2012). Co-localization of QTLs for functional components has been previously found in functional rice, including resistant starch and total alkaloid content in both brown and polished rice (Zeng et al., 2016a). Co-localization of these QTLs may be due to pleiotropy or linkage (Li et al., 2015b). Six QTLs with pleiotropic effects were found between markers Bmag353 and GBM1482 on chromosome $4 \mathrm{H}$ in barley (Chen et al., 2014). These results show that there was at least partial genetic overlap between $\mathrm{K}, \mathrm{Mg}$, and Ca concentrations in the RIL population, which is similar to co-localizations of QTLs for functional components. The present study will be useful for genetic improvement programs

Genetics and Molecular Research 15 (4): gmr15049103 
aiming to increase the concentrations of $\mathrm{K}, \mathrm{Mg}$, and $\mathrm{Ca}$ in barley grains. Cultivar improvement can be obtained with relative ease by molecular breeding. The molecular mechanisms for the larger additive effects observed in $\mathrm{K}, \mathrm{Mg}$, and $\mathrm{Ca}$ concentrations await deeper investigation.

\section{Detection of QTLs for eight element concentrations in barley grass powder}

Seven QTLs for $\mathrm{K}, \mathrm{Mg}, \mathrm{Ca}, \mathrm{Fe}, \mathrm{Zn}$, and $\mathrm{Cu}$ concentrations in barley grass powder were unreported so far. These explained from 6.03 to $21.86 \%$ of the phenotypic variance in the RIL population in this study (Table 3). The average PVE of $q \mathrm{Ca} 3$ and $q K 5$ were 21.85 and $16.45 \%$, respectively, indicating that they were major QTLs for the $\mathrm{Ca}$ and $\mathrm{K}$ concentrations in grass powder. Comparisons of the QTLs identified in this study with previously reported K concentrations in maize and tobacco leaves revealed that $\mathrm{K}$ concentrations were shown to have larger effects. For instance, the highest LOD score of 15.52 was detected for K concentration in leaves of an intermated B73 x Mo17 maize population, explaining more than $20 \%$ of the phenotypic variance (Zdunić et al., 2014). The K content has been shown to be higher during the early stages of tobacco growth; however, some tobacco seedling genes constituted an important gene-regulatory network under early low-potassium stress (Li et al., 2016). Future research should focus on a comprehensive analysis of the gene-regulatory network of $\mathrm{K}$ and $\mathrm{Ca}$ concentration in barley grass.

\section{Conflicts of interest}

The authors declare no conflict of interest.

\section{ACKNOWLEDGMENTS}

Research supported by the National Natural Science Foundation of China (\#31260326), China Agriculture Research System (\#CARS-05), and the Science and Technology to Benefit the People from Yunnan Provincial Scientific and Technology Department (\#2014RA060). We are highly grateful to Leibniz Institute of Plant Genetics and Crop Plant Research (IPK) represented by its Managing Director, Prof. Dr. A. Graner and its Head of Administration, Dr. J. Heilmann as well as to Dr. B. Leps and Dr. M. Röder for their help in offering 25 GBMS primers sequences. We also express our sincere thanks to students Y. Ma, X.Q. He, and L.J. Cun for participating in the SSR molecular markers experiments.

\section{REFERENCES}

Arai H and Sakuma M (2015). [Bone and Nutrition. Bone and phosphorus intake]. Clin. Calcium 25: 967-972.

Armah SM, Carriquiry AL and Reddy MB (2015). Total iron bioavailability from the US diet is lower than the current estimate. J. Nutr. 145: 2617-2621. http://dx.doi.org/10.3945/jn.115.210484

Chang B, Schlussel Y, Sukumar D, Schneider SH, et al. (2015). Influence of vitamin D and estrogen receptor gene polymorphisms on calcium absorption: BsmI predicts a greater decrease during energy restriction. Bone 81: 138-144. http://dx.doi.org/10.1016/j.bone.2015.07.011

Chen WY, Liu ZM, Deng GB, Pan ZF, et al. (2014). Genetic relationship between lodging and lodging components in barley (Hordeum vulgare) based on unconditional and conditional quantitative trait locus analyses. Genet. Mol. Res. 13: 1909-1925. http://dx.doi.org/10.4238/2014.March.17.19

Chen X, Guo X, Ma J, Zhang J, et al. (2015). Urinary sodium or potassium excretion and blood pressure in adults of Shandong province, China: preliminary results of the SMASH project. J. Am. Soc. Hypertens. 9: 754-762. http:// dx.doi.org/10.1016/j.jash.2015.07.004

Genetics and Molecular Research 15 (4): gmr15049103 
$\mathrm{Cu}$ S, Collins HM, Betts NS, March TJ, et al. (2016). Water uptake in barley grain: Physiology; genetics and industrial applications. Plant Sci. 242: 260-269. http://dx.doi.org/10.1016/j.plantsci.2015.08.009

Drewnowski A, Rehm CD, Maillot M, Mendoza A, et al. (2015a). The feasibility of meeting the WHO guidelines for sodium and potassium: a cross-national comparison study. BMJ Open 5: e006625. http://dx.doi.org/10.1136/ bmjopen-2014-006625

Drewnowski A, Tang W and Brazeilles R (2015b). Calcium requirements from dairy foods in France can be met at low energy and monetary cost. Br. J. Nutr. 114: 1920-1928. http://dx.doi.org/10.1017/S0007114515003669

Fiust A, Rapacz M, Wójcik-Jagła M and Tyrka M (2015). Development of DArT-based PCR markers for selecting drought-tolerant spring barley. J. Appl. Genet. 56: 299-309. http://dx.doi.org/10.1007/s13353-015-0273-x

Fuss JO, Tsai CL, Ishida JP and Tainer JA (2015). Emerging critical roles of Fe-S clusters in DNA replication and repair. Biochim. Biophys. Acta 1853: 1253-1271.http://dx.doi.org/10.1016/j.bbamcr.2015.01.018

Garcia-Oliveira AL, Tan L, Fu Y and Sun C (2009). Genetic identification of quantitative trait loci for contents of mineral nutrients in rice grain. J. Integr. Plant Biol. 51: 84-92. http://dx.doi.org/10.1111/j.1744-7909.2008.00730.x

Gorczyca AM, He K, Xun P, Margolis KL, et al. (2015). Association between magnesium intake and risk of colorectal cancer among postmenopausal women. Cancer Causes Control 26: 1761-1769. http://dx.doi.org/10.1007/s10552$\underline{015-0669-2}$

Hejcman M, Berková M and Kunzová E (2013). Effect of long-term fertilizer application on yield and concentrations of elements (N, P, K, Ca, Mg, As, $\mathrm{Cd}, \mathrm{Cu}, \mathrm{Cr}, \mathrm{Fe}, \mathrm{Mn}, \mathrm{Ni}, \mathrm{Pb}, \mathrm{Zn})$ in grain of spring barley. Plant Soil Environ. 59: 329-334.

Huang Y, Sun C, Min J, Chen Y, et al. (2015). Association mapping of quantitative trait loci for mineral element contents in whole grain rice (Oryza sativa L.). J. Agric. Food Chem. 63: 10885-10892. http://dx.doi.org/10.1021/acs. jafc. 5 b04932

Huang Y, Tong C, Xu F, Chen Y, et al. (2016). Variation in mineral elements in grains of 20 brown rice accessions in two environments. Food Chem. 192: 873-878. http://dx.doi.org/10.1016/j.foodchem.2015.07.087

Hui QS and Tian TL (2010). Measurement and analysis of trifling elements in barley plants. China Pract. Med. 5: 15-17.

Jin T, Chen J, Zhu L, Zhao Y, et al. (2015). Comparative mapping combined with homology-based cloning of the rice genome reveals candidate genes for grain zinc and iron concentration in maize. BMC Genet. 16: 17. http://dx.doi. org $/ 10.1186 / \mathrm{s} 12863-015-0176-1$

Kashian $\mathrm{S}$ and Fathivand AA (2015). Estimated daily intake of $\mathrm{Fe}, \mathrm{Cu}, \mathrm{Ca}$ and $\mathrm{Zn}$ through common cereals in Tehran, Iran. Food Chem. 176: 193-196. http://dx.doi.org/10.1016/j.foodchem.2014.12.021

Lahouar L, El-Bok S and Achour L (2015). Therapeutic potential of young green barley leaves in prevention and treatment of chronic diseases: an overview. Am. J. Chin. Med. 43: 1311-1329. http://dx.doi.org/10.1142/S0192415X15500743

Li H, Chen G and Yan W (2015a). Molecular characterization of barley 3H semi-dwarf genes. PLoS One 10: e0120558. http://dx.doi.org/10.1371/journal.pone. 0120558

Li LQ, Li J, Chen Y, Lu YF, et al. (2016). De novo transcriptome analysis of tobacco seedlings and identification of the early response gene network under low-potassium stress. Genet. Mol. Res. 15: gmr.15038599.

Li Y, Wei JK, Li ZQ, Lei AN, et al. (2015b). Quantitative trait locus analysis of leaf morphological characters, yieldrelated traits, and secondary metabolite contents in Eucommia ulmoides. Genet. Mol. Res. 14: 17871-17884. http:// dx.doi.org/10.4238/2015.December.22.12

Lin XX (2005). Preparation and study on barley green-a new natural protection food. Food Sci. Technol. (Campinas) 7: 91-99.

McCouch SR, Cho YG, Yato M, Paul E, et al. (1997). Report on QTL nomenclature. Rice Genet. Newsl. 14: 11-13.

Meng L, Li HH, Zhang LY and Wang JK (2015). QTL IciMapping: integrated software for genetic linkage map construction and quantitative trait locus mapping in bi-parental populations. Crop J. 3: 269-283. http://dx.doi. org/10.1016/j.cj.2015.01.001

Myers SS, Zanobetti A, Kloog I, Huybers P, et al. (2014). Increasing CO2 threatens human nutrition. Nature 510: 139-142. http://dx.doi.org/10.1038/nature13179

Newman RK and Newman CW (2008). Barley for food and health: science, technology, and products. John Wiley \& Sons, Inc, New Jersey.

Noh HM, Park SY, Lee HS, Oh HY, et al. (2015). Association between high blood pressure and intakes of sodium and potassium among Korean adults: Korean national health and nutrition examination survey, 2007-2012. J. Acad. Nutr. Diet. 115: 1950-1957.http://dx.doi.org/10.1016/j.jand.2015.04.021

Ren XF, Sun DF, Dong WB, Sun GL, et al. (2014). Molecular detection of QTL controlling plant height components in a doubled haploid barley population. Genet. Mol. Res. 13: 3089-3099. http://dx.doi.org/10.4238/2014.April.17.5

Rogers OS and Bendich AJ (1988). Extraction of DNA from plant tissues. In: Plant molecular biology manual (Glevin SB \& Schilperoort RA, eds.). Kluwer Academic Publishers, Dordrecht, 1-10.

Genetics and Molecular Research 15 (4): gmr15049103 
Fernandes Santos CA and Boiteux LS (2015). Genetic control and transgressive segregation of zinc, iron, potassium, phosphorus, calcium, and sodium accumulation in cowpea (Vigna unguiculata) seeds. Genet. Mol. Res. 14: 259-268. http://dx.doi.org/10.4238/2015.January.16.10

Santos T, Connolly C and Murphy R (2015). Trace element inhibition of phytase activity. Biol. Trace Elem. Res. 163: 255-265. http://dx.doi.org/10.1007/s12011-014-0161-y

Schiller M, Hegelund JN, Pedas P, Kichey T, et al. (2014). Barley metallothioneins differ in ontogenetic pattern and response to metals. Plant Cell Environ. 37: 353-367.http://dx.doi.org/10.1111/pce.12158

Shiraki M (2015). [Health benefits and demerits of calcium nutrition or supplementation in older people]. Nihon Rinsho 73: $1770-1776$.

Simić D, Mladenović Drinić S, Zdunić Z, Jambrović A, et al. (2012). Quantitative trait loci for biofortification traits in maize grain. J. Hered. 103: 47-54. http://dx.doi.org/10.1093/jhered/esr122

Sørensen LB, Damsgaard CT, Dalskov SM, Petersen RA, et al. (2015). Diet-induced changes in iron and n-3 fatty acid status and associations with cognitive performance in 8-11-year-old Danish children: secondary analyses of the Optimal Well-Being, Development and Health for Danish Children through a Healthy New Nordic Diet School Meal Study. Br. J. Nutr. 114: 1623-1637. http://dx.doi.org/10.1017/S0007114515003323

Varshney RK, Marcel TC, Ramsay L, Russell J, et al. (2007). A high density barley microsatellite consensus map with 775 SSR loci. Theor. Appl. Genet. 114: 1091-1103. http://dx.doi.org/10.1007/s00122-007-0503-7

Wang J, Yang J, Zhang Q, Zhu J, et al. (2015a). Mapping a major QTL for malt extract of barley from a cross between TX9425 × Naso Nijo. Theor. Appl. Genet. 128: 943-952. http://dx.doi.org/10.1007/s00122-015-2481-5

Wang JK (2009). Inclusive composite interval mapping of quantitative trait genes. Acta Agron. Sin. 35: 239-245. http:// dx.doi.org/10.3724/SP.J.1006.2009.00239

Wang X, Zhang X, Cai S, Ye L, et al. (2015b). Genetic diversity and QTL mapping of thermostability of limit dextrinase in barley. J. Agric. Food Chem. 63: 3778-3783. http://dx.doi.org/10.1021/acs.jafc.5b00190

Yan J, Wang F, Yang RZ, Xiao TF, et al. (2012). Natural variation in grain iron and zinc concentrations of wild barley, Hordeum spontaneum, populations from Israel. In: Advance in barley sciences: proceedings of 11th international barley genetics symposium (Zhang GP, Li CD and Liu X, eds.). Zhejiang University Press, Hangzhou, 102-112.

Yang JZ, Zeng YW, Yang XM, Pu XY, et al. (2016). Utilization of barley functional foods for preventing chronic diseases in China. Agri. Sci. Technol 17: 2195-2204.

Yu YH, Shao YF, Liu J, Fan YY, et al. (2015). Mapping of quantitative trait loci for contents of macro- and microelements in milled rice (Oryza sativa L.). J. Agric. Food Chem. 63: 7813-7818. http://dx.doi.org/10.1021/acs.jafc.5b02882

Zdunić Z, Grljušić S, Ledenčan T, Duvnjak T, et al. (2014). Quantitative trait loci mapping of metal concentrations in leaves of the maize IBM population. Hereditas 151: 55-60.http://dx.doi.org/10.1111/hrd2.00048

Zeng Y, Zhang H, Wang L, Pu X, et al. (2010). Genotypic variation in element concentrations in brown rice from Yunnan landraces in China. Environ. Geochem. Health 32: 165-177.http://dx.doi.org/10.1007/s10653-009-9272-3

Zeng YW, Wang LX, Du J, Yang SM, et al. (2009). [Correlation of mineral elements between milled and brown rice and soils in Yunnan studied by ICP-AES]. Guangpuxue Yu Guangpu Fenxi 29: 1413-1417.

Zeng YW, Pu XY, Zhang J, Guo GG, et al. (2013). Synthetic research and utilization on industrial development of barley in Southwestern China. J. Agric. Sci. Technol.; JAST 15: 48-56.

Zeng YW, Sun D, Du J, Pu XY, et al. (2016a). Identification of QTLs for resistant starch and total alkaloid content in brown and polished rice. Genet. Mol. Res. 15: gmr.15037268.

Zeng YW, Yang JZ, Pu XY, Du J, et al. (2016b). Strategies of functional foods for heart disease prevention in human being. 2016 The International Conference on Environmental Research and Public Health. October 21- 23, 2016, Shenzhen. Availabe at [http://www.icerp2016.org/]

Genetics and Molecular Research 15 (4): gmr15049103 